\title{
POLA ARGUMENTASI PADA GENRE TEKS EKSPOSISI KARANGAN SISWA SMA
}

\author{
Nurul Khairani Abduh ${ }^{1}$, Andoyo Sastromiharjo ${ }^{2}$, dan Dadang S. Anshori ${ }^{3}$ \\ ${ }^{1}$ Institut Agama Islam Negeri Palopo \\ Jalan Agatis, Balandai, Kota Palopo, Sulawesi Selatan \\ ${ }^{2,3}$ Universitas Pendidikan Indonesia, Bandung \\ Jalan Dr. Setiabudi No. 229 Bandung, Jawa Barat \\ Surel: nurulkhairani@iainpalopo.ac.id.
}

InformasiArtikel:
Dikirim: 23 November 2018; Direvisi: 23 Januari 2019; Diterima: 1 Februari 2019
DOI: 10.26858/retorika.v12i1.7372
RETORIKA: Jurnal Bahasa, Sastra dan Pengajarannya berada di bawah lisensi
Creative Commons Attribution-NonCommercial 4.0 International License.
ISSN: 2614-2716 (cetak), ISSN: 2301-4768 (daring)
http://ojs.unm.ac.id/retorika

\begin{abstract}
Abstrack. Argumentation Pattern on Genres of Exposition Texts by High School Students. This article aims to describe the pattern of argumentation in the essays of student expositions based on the theoretical study of Toulmin's Argumentation Pattern (TAP). The documentation technique was used in data collection in sources in the form of expositions of class X students from five schools in Makassar City, namely Makassar 14 High School (24 data), Makassar 4 Public High School, Makassar 9 Public High School, Athirah Makassar Islamic High School, and SMA Tri Tunggal 45 Makassar. The results of the analysis show nine argumentation patterns produced in the exposition essay, ranging from the most basic and simple patterns to the most complex patterns, namely (1) C-D, (2) C-D-W, (3) C-D-Q, (4) C-D-R, (5) C-D-W-B, (6) C-D-WQ, (7) C-D-W-R, (8) C-D-Q-R, and (9) C-D-W-B-Q.
\end{abstract}

Keywords: argumentation patterns, genre of text, exposition text

\begin{abstract}
Abstrak: Pola Argumentasi pada Genre Teks Eksposisi Karangan Siswa SMA. Artikel ini bertujuan untuk mendeskripsikan pola argumentasi dalam karangan eksposisi siswa berdasarkan kajian teoretis Toulmin's Argumentation Pattern (TAP). Teknik dokumentasi digunakan dalam pengumpulan data yang bersumber dari data karangan eksposisi siswa kelas X dari lima sekolah yang ada di Kota Makassar, yaitu SMA Negeri 14 Makassar, SMA Negeri 4 Makassar, SMA Negeri 9 Makassar, SMA Islam Athirah Makassar, dan SMA Tri Tunggal 45 Makassar. Hasil analisis menunjukkan sembilan pola argumentasi yang dihasilkan dalam karangan eksposisi tersebut, mulai dari pola paling dasar dan sederhana hingga pola yang paling kompleks, yaitu (1) C-D, (2) C-D-W, (3) C-D-Q, (4) C-D-R, (5) C-D-W-B, (6) C-D-W-Q, (7) C-D-W-R, (8) C-D-QR, dan (9) C-D-W-B-Q.
\end{abstract}

Kata kunci: pola argumentasi, genre teks, teks eksposisi 
72 RETORIKA: Jurnal Bahasa, Sastra, dan Pengajarannya,

Kurikulum 2013 yang berlaku saat ini berdasar pada pondasi teoretik pengembangan pendekatan komunikatif, pendekatan genre-based, dan CLIL (Content Language Integrated Learning). Teks dalam pendekatan berbasis genre bukan diartikan istilah umum sebagai tulisan berbentuk artikel. Teks merupakan kegiatan sosial dan tujuan sosial. Tujuan sosial melalui bahasa berbeda-beda sesuai tujuan. Pencapaian tujuan ini diwadahi oleh karakteristik cara mengungkapkan tujuan sosial yang disebut struktur retorika, pilihan kata yang sesuai dengan tujuan, dan tata bahasa yang sesuai dengan tujuan. Misalnya, tujuan sosial eksposisi (berpendapat) memiliki struktur retorika tesis-argumen (Harsiati, dkk., 2017:4). Mengacu pada kurikulum 2013 tersebut, pembelajaran berbasis teks yang mengandung penalaran argumentatif dan diajarkan di sekolah adalah pembelajaran teks eksposisi. Teks eksposisi dalam Kurikulum 2013 bukan lagi hanya diajarkan sebagai sekadar teks yang memberikan penjelasan mengenai informasi, melainkan juga menguraikan argumentasi.

Jenis teks eksposisi ini merupakan jenis karangan yang mengandung argumen-argumen dalam struktur pembangun teksnya. Hal ini dijelaskan oleh Knapp \& Watkins (2013:191) yang mengatakan bahwa di sekolah, argumen tertulis cenderung berfokus pada dua tipe utama: eksposisi dan diskusi. Oleh karena itu, dalam mengajarkan jenis teks ini disarankan agar memulainya dengan eksposisi, jenis teks yang secara jelas memfokuskan siswa pada tujuan argumen; artinya, yang mengedepankan sudut pandang dan memberikan bukti yang mendukung. Senada dengan itu, Maryanto, dkk. (2013:176) mengemukakan bahwa eksposisi adalah jenis teks yang berfungsi untuk mengungkapkan gagasan atau mengusulkan sesuatu berdasarkan argumentasi yang kuat. Lebih lanjut, dijelaskan bahwa teks eksposisi hanya berisi satu sisi argumentasi, yakni sisi yang mendukung atau sisi yang menolak. Struktur teksnya adalah pernyataan pendapat (tesis), argumentasi, dan penegasan ulang pendapat.

Pola argumentasi dapat dikaji dengan menggunakan teori dari Toulmin yang dikenal dengan Toulmin's Argument Pattern (TAP). Toulmin, dkk. (1979) mengungkapkan bahwa tulisan argumentasi memiliki elemen-elemen yang membangun struktur tulisannya. Elemenelemen tersebut terbagi menjadi enam bagian, meliputi (1) pernyataan/tesis (claim), (2) alasan/ bukti-bukti (grounds/data), (3) pembenaran/ kaidah-kaidah/prinsip-prinsip (warrant), (4) du- kungan (background/backing), (5) modalitas (modal qualifier), (6) kemungkinan bantahan (rebuttal). Berdasarkan persepektif Toulmin ini, sebuah argumentasi mencakup claim yang menjadi penyataan posisi atau pernyataan yang diyakini oleh argumentator, data yang dihadirkan untuk mendukung claim, warrants yang menghubungkan antara data dan claim, backing yang memperkuat warrant, dan rebuttals yang menunjukkan kemungkinan sanggahan terhadap claim yang diajukan. Skema pembentukan argumen Toulmin ditunjukkan pada Gambar 1.

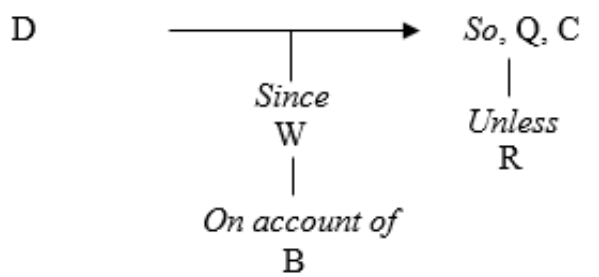

Gambar 1. Skema Argumentasi Toulmin, dkk. (1979)

Penyusunan elemen-elemen argumen lebih ditekankan pada pernyataan-pernyataan yang membangun argumen-argumen tersebut. Artinya, setelah claim didapat maka akan timbul pertanyaan mengapa ada claim demikian atau seperti apa bukti claim itu. Kemudian, ditampilkan data. Setelah data diperoleh, muncul lagi pertanyaan apa sebenarnya yang menjadi penguat claim dan yang menghubungkan data dengan claim tersebut. Untuk itu, muncullah warrant. Warrant ini lantas dipertanyakan lagi, yaitu apa latar belakang kemunculan warrant tadi. Lalu ditampilkanlah backing. Ketika elemen-elemen berupa claim, data, warrant, dan backing itu memungkinkan muncul kondisi yang berlawanan, maka dapat pula muncul rebuttal yang umumnya disyaratkan oleh qualifier.

Penelitian yang menganalisis pola argumentasi menggunakan teori TAP ini telah dilakukan oleh Kathpalia \& Eng (2016) yang meneliti argumentasi dalam tulisan blog siswa. Di Indonesia, penelitian mengenai paragraf argumentasi dengan menggunakan TAP juga pernah dilakukan oleh Syaifuddin, dkk. (2011), Handayani (2015), Dilianzia (2015), dan Viyanti (2015). Keempat peneliti menggunakan teori Toulmin's Argument Pattern (TAP) sebagai model analisis untuk menemukan pola argumentasi dari bidang keilmuan sains dan seni rupa.

Hal berbeda yang dilakukan dalam penelitian ini adalah penelitian yang dilakukan meng- 
Tabel 1. Glosarium Kriteria Elemen Argumentasi Toulmin

\begin{tabular}{|c|c|}
\hline Elemen & Kriteria \\
\hline $\begin{array}{l}\text { Claim } \\
\text { (pernyataan } \\
\text { posisi) }\end{array}$ & $\begin{array}{l}\text { 1. Pernyataan tegas yang dapat diterima secara umum dengan maksud mendasari sebuah } \\
\text { pemikiran } \\
\text { 2.Pernyataan yang berisi gagasan atau pendapat atau posisi seseorang terhadap suatu } \\
\text { masalah } \\
\text { 3. Claim berisi tujuan penulis/argumentator sehingga apabila ingin mengetahui apa yang } \\
\text { menjadi tujuan sebuah argumen, dapat dilihat pada claim tersebut. } \\
\text { 4. Pertanyaan yang bisa diajukan untuk menemukan/menganalisis claim, yaitu: "apa yang } \\
\text { menjadi pernyataan posisi Anda?" atau "di mana Anda berdiri dalam masalah ini?" atau } \\
\text { "apa yang menjadi poin utama yang ingin disampaikan penulis?" }\end{array}$ \\
\hline $\begin{array}{l}\text { Data/Ground } \\
\text { (alasan/bukti- } \\
\text { bukti) }\end{array}$ & $\begin{array}{l}\text { 1. Fakta-fakta yang mendukung claim dan menjadi pondasi bagi claim yang diajukan. } \\
\text { 2. Claim selalu didukung oleh alasan, yaitu pernyataan yang diberi keterangan fakta-fakta } \\
\text { khusus tentang sebuah situasi untuk memperjelas claim tersebut. } \\
\text { 3. Data dapat berupa data statistik, contoh, ilustrasi, penalaran, observasi eksperimental, } \\
\text { materi ilmu pengetahuan umum, maupun pengujian. } \\
\text { 4. Pertanyaan untuk menganalisis data: "apa yang menjadi alasan dan bukti untuk } \\
\text { mendukungnya?" atau "apa alasan mendasar dari claim Anda?" }\end{array}$ \\
\hline $\begin{array}{l}\text { Warrant } \\
\text { (pembenaran/ } \\
\text { kaidah- } \\
\text { kaidah/prinsip } \\
\text {-prinsip) }\end{array}$ & $\begin{array}{l}\text { 1. Pernyataan yang menghubungkan claim dan data sehingga membentuk alasan utama yang } \\
\text { menguatkan argumen. } \\
\text { 2. Warrants merupakan pernyataan umum yang menunjukkan hubungan claim dan } \\
\text { data/grounds sehingga argumen lebih meyakinkan. } \\
\text { 3. Warrant disebut juga pembenaran atau jaminan yang menunjukkan kaidah-kaidah umum } \\
\text { untuk mempertahankan pernyataan. Dengan alasan dan pernyataan, pembenaran dapat } \\
\text { dipertahankan dan diterima secara rasional. } \\
\text { 4. Pernyataan untuk menganalisis warrant: "bagaimana Anda menjembatani data ke claim?" } \\
\text { atau "apa yang menjadi jaminan untuk menguatkan bukti dan sekaligus menjadi } \\
\text { penghubung keduanya?" }\end{array}$ \\
\hline $\begin{array}{l}\text { Backing } \\
\text { (dukungan) }\end{array}$ & $\begin{array}{l}\text { 1. Data tambahan yang memastikan posisi warrant sebagai penghubung. } \\
\text { 2. Pemberi argumen membutuhkan warrant yang didukung dengan hal-hal tertentu (di sini } \\
\text { kita sebut sebagai backing). } \\
\text { 3. Pemberi argumen setidaknya dapat memberikan sesuatu yang menunjukkan bahwa } \\
\text { warrants yang telah dikemukakan dapat berdiri sendiri dengan backing. Dengan cara ini } \\
\text { maka warrants yang telah ditempeli oleh backing akan mendukung argumen asli, dalam } \\
\text { hal ini claim dan data. } \\
\text { 4. Biasanya berisi hasil penelitian atau pendapat para ahli. } \\
\text { 5. Pertanyaan untuk menganalisis backing: "apa yang mendukung Warrant?"” }\end{array}$ \\
\hline $\begin{array}{l}\text { Modal } \\
\text { Qualifier } \\
\text { (modalias) }\end{array}$ & $\begin{array}{l}\text { 1. Pernyataan yang berupa sikap, gaya, dan nada argumen yang bertujuan untuk } \\
\text { memengaruhi pembaca argumen. } \\
\text { 2. Modalitas menunjukkan seberapa kuatnya argumen. } \\
\text { 3. Kata atau frasa yang menunjukkan derajat kepastian atau kualitas suatu pernyataan. } \\
\text { 4. Modalitas biasanya berbentuk kata keterangan, seperti perlunya, pastinya, tentunya, } \\
\text { biasanya, normalnya, kemungkinan besar, rupanya, mungkin, dll. } \\
\text { 5. Modal dibagi dua, yakni penanda kepastian dan penanda kemungkinan. Perlu, pasti, tentu } \\
\text { saja, agaknya, kiranya, rupanya, kemungkinannya, sejauh bukti yang ada, sangat } \\
\text { mungkin, mungkin sekali, masuk akal dll. } \\
\text { 6. Pertanyaan untuk menganalisis modalitas: "adakah kata atau frasa yang menunjukkan } \\
\text { derajat kepastian claim? }\end{array}$ \\
\hline $\begin{array}{l}\text { Rebuttal } \\
\text { (kemungkinan } \\
\text { bantahan/ } \\
\text { pengecualian) }\end{array}$ & $\begin{array}{l}\text { 1. Pernyataan yang menafikkan argumen yang posisinya justru akan menguatkan argumen } \\
\text { jika dimunculkan dalam argumen. } \\
\text { 2. Kemungkinan bantahan atau sanggahan, yaitu persiapan ketika claim mendapat sanggahan } \\
\text { atas pengecualian terhadap claim. } \\
\text { 3. Penggunaan elemen sanggahan juga berarti membuat pernyataan menjadi lebih spesifik. } \\
\text { 4. Piranti kohesi yang digunakan menandai elemen sanggahan adalah kecuali, jika .... maka } \\
\text { dan jika } \\
\text { 5. Pertanyaan untuk menganalisis rebuttal: "adakah kemungkinan sanggahan atau bantahan } \\
\text { terhadap claim? }\end{array}$ \\
\hline
\end{tabular}


74 RETORIKA: Jurnal Bahasa, Sastra, dan Pengajarannya,

Volume 12, Nomor 1, Februari 2019, hlm. 71-84

analisis karangan eksposisi yang mengandung argumentasi dalam teks siswa untuk menemukan pola argumentasi berdasarkan teori Toulmin's Argument Pattern (TAP) yang dikemukakan oleh Toulmin, dkk. (1979). Hasil penelitian akan berguna untuk mengetahui gambaran profil pola argumentasi pada karangan eksposisi siswa SMA.

\section{METODE}

Penelitian ini menggunakan pendekatan kualitatif dengan metode penelitian deskriptif. Sebagaimana dijelaskan Moleong (2017) bahwa penelitian kualitatif adalah penelitian yang bermaksud untuk memahami fenomena tentang apa yang dialami oleh subjek penelitian, misalnya perilaku, persepsi, motivasi, tindakan, dan lain-lain secara holistik dan dengan cara deskripsi dalam bentuk kata-kata dan bahasa pada suatu konteks khusus yang alamiah dan dengan memanfaatkan berbagai metode alamiah. Penelitian ini mengkaji fenomena dari data yang diperoleh di lapangan secara alamiah tanpa memberikan perlakuan apa pun kepada objek penelitian.

Orientasi teoretis yang digunakan dalam penelitian ini adalah argumentasi Toulmin yang dikenal dengan Toulmin's Argument Pattern (TAP). Teori ini berguna dalam memberikan penafsiran makna dan paradigma berpikir siswa dalam menyusun karangan eksposisi yang berisi argumentasi dalam teksnya.

Sumber data yang digunakan dalam penelitian ini adalah dokumen tugas teks eksposisi dari siswa sekolah menengah atas kelas $\mathrm{X}$ yang terdiri atas lima sekolah SMA yang ada di Kota Makassar, yaitu SMA Negeri 14 Makassar, SMA Negeri 4 Makassar, SMA Negeri 9 Makassar, SMA Islam Athirah Makassar, dan SMA Tri Tunggal 45 Makassar. Jumlah dokumen tugas yang diperoleh dari tiap sekolah berbeda berdasarkan jumlah siswa yang ada dalam satu kelas yang dijadikan sumber data. Total keseluruhan data yang diperoleh dalam penelitian ini adalah sebanyak 117 data. Terdapat tujuh data yang tidak dapat dianalisis karena gagasan antarkalimat yang tidak saling mendukung, banyak data yang menunjukkan struktur karangan yang tidak lengkap, dan data tidak mengandung elemen claim yang merupakan pernyataan posisi penulis dalam argumentasi yang akan dibuktikan. Jadi, total keseluruhan data yang dianalisis dalam penelitian ini adalah sebanyak 110 data.

Untuk mendapatkan berbagai data yang digunakan dalam penelitian digunakan teknik do- kumentasi. Teknik dokumentasi dilakukan dengan mengambil karangan siswa dari setiap kelas di sekolah sekolah kemudian dianalisis. Teknik pengumpulan data dilakukan melalui prosedur: (1) mengambil atau menugaskan siswa mengarang tulisan eksposisi di setiap satu kelas dari lima sekolah yang ada di Kota Makassar; (2) menyimak atau menelaah dengan cermat semua tulisan eksposisi siswa dari lima sekolah SMA yang ada di Kota Makassar; (3) menganalisis pola dan kadar ketajaman argumentasi berdasarkan teori Stephen Toulmin atau Toulmin's Argumentative Pattern (TAP); (4) melakukan triangulasikan data dan mencatatnya pada kartu data sesuai masalah yang dirumuskan.

Instrumen penelitian yang digunakan dalam penelitian ini adalah peneliti sebagai instrumen utama dan kartu data teks eksposisi siswa. Kartu data berupa teks eksposisi dari siswa yang kemudian polanya diklasifikasikan berdasarkan acuan teoretis Toulmin's Argument Pattern (TAP). Untuk memudahkan dalam menganalisis setiap elemen argumentasi berdasarkan teori Toulmin's Argument Pattern (TAP) digunakan glosarium yang menjadi acuan untuk menentukan kriteria setiap elemen argumentasi (Tabel 1).

\section{HASIL DAN PEMBAHASAN}

Karangan eksposisi siswa menghasilan sembilan pola. Temuan itu mencakup pola yang sederhana hingga pola argumentasi yang lebih kompleks berdasarkan teori Toulmin's Argument Pattern (TAP). Kesembilan pola tersebut adalah C-D, C-D-W, C-D-Q, C-D-R, C-D-W-B, C-DW-Q, C-D-W-R, C-D-Q-R, dan C-D-W-B-Q. Kesembilan pola hasil analisis data tersebut dibuatkan glosarium sebagai panduan yang dapat dilihat pada Tabel 1 .

Tabel 2. Rekapitulasi Ragam Pola yang Muncul

\begin{tabular}{cccc}
\hline No. & Pola & $\begin{array}{c}\text { Jumlah } \\
\text { Data }\end{array}$ & Persentase \\
\hline 1 & C-D & 44 & $40 \%$ \\
2 & C-D-W & 7 & $6,36 \%$ \\
3 & C-D-Q & 46 & $41,82 \%$ \\
4 & C-D-R & 1 & $0,91 \%$ \\
5 & C-D-W-B & 1 & $0,91 \%$ \\
6 & C-D-W-Q & 8 & $7,27 \%$ \\
7 & C-D-W-R & 1 & $0,91 \%$ \\
8 & C-D-Q-R & 1 & $0,91 \%$ \\
9 & C-D-W-B-Q & 1 & $0,91 \%$ \\
& Total & $\mathbf{1 1 0}$ & $\mathbf{1 0 0 \%}$ \\
\hline
\end{tabular}


Dari Tabel 1, dapat dijelaskan bahwa pola yang paling banyak muncul dalam karangan eksposisi siswa adalah pola C-D-Q dan pola dasar C-D. Walaupun belum ada karangan yang memunculkan keenam elemen argumentasi berdasarkan teori Toulmin's Argument Pattern (TAP), namun sudah ada dua karangan yang berpola C-D-W-B-Q yang hampir memunculkan keseluruhan elemen TAP. Berikut dideskripsikan pola yang muncuk berdasarkan hasil penelitian.

\section{Argumentasi Berpola C-D}

Pola C-D merupakan pola yang terdiri atas elemen claim dan data dalam karangan. Pola ini merupakan pola yang paling dasar menurut Toulmin. Penulis memunculkan kalimat yang berisi pernyataan posisi terhadap sesuatu kemudian diikuti dengan alasan atau bukti terhadap pernyataan yang dimunculkan. Pola ini merupakan pola dasar yang menjadi kemampuan awal yang harus bisa dilakukan seseorang dalam berargumen. Penulis memunculkan gagasan berdasarkan pendapat atau pandangannya kemudian berusaha memberikan alasan-alasan dan buktibukti yang mendukung terhadap gagasan tersebut. Bukti-bukti yang dimunculkan disebut juga data atau ground.

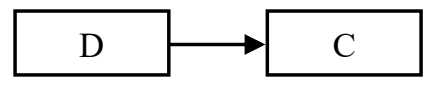

Bagan 1. Pola C-D
Pada Bagan 1 terlihat bahwa data atau disebut juga grounds mendukung claim sebagai pernyataan posisi. Dalam sebuah karangan, posisi claim tidak selamanya berada di awal lalu diikuti oleh grounds atau data. Posisinya bisa saja bertukar. Diawali oleh sekumpulan faktafakta pendukung lebih dahulu lalu diakhiri oleh sebuah kesimpulan yang menjadi pernyataan posisi dari penulis terhadap fakta-fakta yang diuraikan. Sebuah kesimpulan dalam argumentasi memiliki fungsi yang sama dengan claim, yakni sebuah pernyataan yang memerlukan pembuktian. Hal ini sebagaimana yang dikemukakan oleh Weston (2007:9) bahwa kesimpulan adalah suatu pernyataan yang untuk itu diberi alasanalasan. Meskipun posisi keduanya bisa sa-ling bertukar, tetap saja argumen tersebut meng-ikuti pola dasar yang ada, yaitu pola C-D. Tabel 2 menunjukkan data yang menggunakan argumentasi dengan pola C-D.

Karangan pada Tabel 3 diawali dengan claim yang menyatakan tentang "perubahan" yang terjadi dalam sistem kurikulum Indonesia. Pernyataan claim ini didukung oleh bukti yang menjelaskan tentang kurikulum 2006 yang berubah menjadi kurikulum 2013. Kalimat-kalimat selanjutnya berisi gagasan-gagasan yang berisi data/grounds yang mendukung gagasan penulis dalam claim mengenai perubahan kurikulum tersebut.

Tabel 3. Pola Argumentasi C-D dalam Karangan Siswa

\begin{tabular}{|c|c|c|c|c|c|c|}
\hline \multicolumn{7}{|l|}{ Komponen Argumentasi } \\
\hline Kalimat & $\mathbf{C}$ & D & W & B & $\mathbf{Q}$ & $\mathbf{R}$ \\
\hline $\begin{array}{l}\text { Sistem pendidikan Indonesia dewasa ini mengalami suatu perubahan yang } \\
\text { sangat signifikan. }\end{array}$ & $\sqrt{ }$ & & & & & \\
\hline $\begin{array}{l}\text { Perubahan tersebut berkaitan dengan kurikulum yang digunakan dalam dunia } \\
\text { pendidikan Indonesia. }\end{array}$ & $\sqrt{ }$ & & & & & \\
\hline $\begin{array}{l}\text { Dimana kurikulum } 2006 \text { yang sejak lama dipakai diganti dengan kurikulum } \\
2013 \text {. }\end{array}$ & & $\sqrt{ }$ & & & & \\
\hline $\begin{array}{l}\text { Walaupun tidak semua sekolah menggunakan kurikulum ini, namun tetap } \\
\text { berjalan sebagaimana mestinya. }\end{array}$ & & $\sqrt{ }$ & & & & \\
\hline $\begin{array}{l}\text { Kementrian pendidikan dan kebudayaan (kemendikbud) dalam beberapa } \\
\text { kesempatan menjelaskan bahwa kurikulum } 2013 \text { diprioritaskan pada sekola- } \\
\text { sekolah yang memiliki akreditasi A atau sekolah berstandar internasional, yang } \\
\text { biasa disingkat dengan RSBI (Rintisan Sekolah Berstandar Internasional). }\end{array}$ & & $\sqrt{ }$ & & & & \\
\hline $\begin{array}{l}\text { Akan tetapi dengan adanya kurikulum } 2013 \text { banyak yang tidak setuju karena } \\
\text { proses belajar mengajar yang terlalu lama sehingga para pelajar kurang fokus } \\
\text { dalam hal pelajaran. }\end{array}$ & $\sqrt{ }$ & $\sqrt{ }$ & & & & \\
\hline Total & 3 & 4 & & & & \\
\hline Pola Argumentasi & \multicolumn{6}{|c|}{ C-D } \\
\hline
\end{tabular}




\section{Argumentasi Berpola C-D-Q}

Berdasarkan hasil analisis, pola ini adalah pola yang paling dominan muncul dalam karangan teks eksposisi siswa. Dari 110 data yang dapat dianalisis, pola ini muncul sebanyak 46 kali $(41,8 \%)$ dari keseluruhan data. Modal qualifier atau (Q) merupakan kata atau frasa penanda yang menunjukkan derajat kepastian claim atau pernyataan posisi. Tabel 4 merupakan salah satu data yang memunculkan pola C-D-Q.

Kata perlu dalam karangan pada Tabel 4 menunjukkan sikap penulis terhadap claim yang diajukan. Modal qualifier ini muncul untuk meyakinkan pembaca bahwa berdasarkan grounds yang diberikan mengenai pro-kontra program full day school harus ada peraturan berupa kebijakan pemerintah yang menjelaskan dan menjawab per-

Tabel 4. Pola Argumentasi C-D-Q dalam Karangan Siswa

\begin{tabular}{|c|c|c|c|c|c|c|}
\hline \multicolumn{7}{|l|}{ Komponen Argumentasi } \\
\hline Kalimat & C & D & $\mathbf{W}$ & B & $\mathbf{Q}$ & $\mathbf{R}$ \\
\hline $\begin{array}{l}\text { Full day school (sekolah satu hari penuh ) merupakan kurikulum yang berlaku saat } \\
\text { ini. }\end{array}$ & $\sqrt{ }$ & & & & & \\
\hline $\begin{array}{l}\text { Program ini mendapat pendapat kontra dikalangan mesyarakat terutama para orang } \\
\text { tua siswa tersebut. }\end{array}$ & $\sqrt{ }$ & & & & & \\
\hline $\begin{array}{l}\text { Masyarakat yang setuju memiliki alasan bahwa waktu sekolah yang ditambah akan } \\
\text { menambah ilmu pengetahuan daripada pulang cepat tapi tidak langsung } \\
\text { kerumahnya masing-masing, seperti yang sering saya liat dibanyak siswa yang } \\
\text { membuang-buang waktu dengan kegiatan yang tidak bermanfaat, misalnya ke mall. }\end{array}$ & & $\sqrt{ }$ & & & & \\
\hline $\begin{array}{l}\text { Program full day school bukan berarti kita belajar sepenuhnya di sekolah, tetapi } \\
\text { kita dapat mengikuti kegiatan ekstrakulikuler yang berguna untuk mengembangkan } \\
\text { bakat/keterampilan. }\end{array}$ & & $\sqrt{ }$ & & & & \\
\hline Program ini masih menjadi kontroversi. & $\sqrt{ }$ & & & & & \\
\hline Banyak yang setuju dan juga tidak setuju. & $\sqrt{ }$ & & & & & \\
\hline $\begin{array}{l}\text { Oleh karena itu, perlu kebijakan bagi pemerintah tentang kurikulum yang berlaku } \\
\text { saat ini. }\end{array}$ & $\sqrt{ }$ & & & & $\sqrt{ }$ & \\
\hline Total & 5 & 2 & & & 1 & \\
\hline Pola Argumentasi & & & & & & \\
\hline
\end{tabular}

Tabel 5. Pola Argumentasi C-D-W dalam Karangan Siswa

\section{Komponen Argumentasi}

\begin{tabular}{|c|c|c|c|c|c|c|}
\hline Kalimat & $\mathbf{C}$ & D & $\mathbf{W}$ & B & $\mathbf{Q}$ & $\mathbf{R}$ \\
\hline $\begin{array}{l}\text { Peran dan manfaat WTO globalisasi memberikan dampak berupa perubahan pada } \\
\text { pasar internasional, salah satunya adalah liberalisasi perdagangan, yang dipandang } \\
\text { sebagai suatu upaya untuk meningkatkan jaya sang ekonomi. }\end{array}$ & & $\sqrt{ }$ & & & & \\
\hline $\begin{array}{l}\text { Indonesia yang menganut perekonomian terbuka sangat sulit mengelak dari } \\
\text { dinamika ekonomi internasional yang semakin mengglobal ini. }\end{array}$ & $\sqrt{ }$ & & & & & \\
\hline $\begin{array}{l}\text { Konsekuensinya, pasar domestik Indonesia tidak terlepas dari gejolak pasar dunia } \\
\text { yang semakin liberal, karena kebijakan unilateral dan raliterasi kerjasama } \\
\text { perdagangan inernasional (regional dan global) yang harus dilakukan Indonesia. }\end{array}$ & & $\sqrt{ }$ & & & & \\
\hline $\begin{array}{l}\text { World Trade Organization (WTO) atau organisasi perdagangan dunia merupakan } \\
\text { satu-satunya badan internasional yang secara khusus menggatur masalah } \\
\text { perdagangan antarnegara. }\end{array}$ & & & $\sqrt{ }$ & & & \\
\hline $\begin{array}{l}\text { Sistem perdagangan multilateral WTO diatur melalui suatu persetujuan yang berisi } \\
\text { aturan-aturan dasar perdagangan internasional sebagai hasil perundangan yang } \\
\text { telah ditandatangani oleh negara-negara anggota. }\end{array}$ & & & $\sqrt{ }$ & & & \\
\hline Total & 1 & 2 & 2 & & & \\
\hline Pola Paragraf & \multicolumn{6}{|c|}{ C-D-W } \\
\hline
\end{tabular}


masalahan terhadap persoalan pro-kontra tersebut. Pola ini memunculkan dua claim dalam satu karangan. Claim berada di awal kalimat yang kemudian diikuti grounds untuk menunjukkan bukti terhadap berlakunya program full day school dan alasan mengenai pendapat kontra di masyarakat. Lalu berdasarkan alasan dan bukti yang diutarakan dalam grounds, penulis membuat satu pernyataan posisi di akhir paragraf. Sikap penulis di claim terakhir menambahkan elemen modal qua-lifier untuk menunjukkan kuatnya argumen.

Modal qualifier dalam hal ini memiliki fungsi untuk menunjukkan sikap atau gaya penulis dalam sebuah argumen untuk memengaruhi pembaca. Modal qualifier ini menunjukkan intensitas argumen dengan mengingat ketersediaan elemen-elemen yang telah dikemukakan. Untuk mendukung claim. Hal ini sesuai dengan pendapat Toulmin, dkk. (1979:88) menjelaskan bahwa modal qualifier dapat digunakan untuk mengukur seberapa kuat atau seberapa baik bukti yang telah dikemukakan untuk mendukung claim.

\section{Argumentasi Berpola C-D-W}

Ada tiga elemen yang muncul dalam pola ini, yaitu claim, data, dan warrant. Elemen keti- ga, yaitu warrant menjadi jaminan yang berisi pernyataan umum yang menghubungkan claim dan data. Seperti yang dikatakan Toulmin (2003:93) bahwa yang dibutuhkan adalah pernyataan umum, pernyataan hipotetis, yang dapat bertindak sebagai jembatan dan mengesahkan jenis langkah dengan argumen tertentu mengikat pemberi argumen (penulis/pembicara). Jadi, warrant dalam hal ini berfungsi sebagai penghubung yang biasanya berisi pernyataan umum atau kaidah-kaidah umum yang juga dikemukakan oleh para ahli atau pakar yang dapat diyakini kebenaran ucapannya. Data karangan siswa yang berpola C-D-W ditunjukkan pada Tabel 4.

\section{Argumentasi Berpola C-D-R}

Melalui analisis data, ditemukan satu data argumentasi dengan pola C-D-R dalam karangan eksposisi siswa SMA. Argumentasi ini diawali dengan kalimat berisi claim yang diikuti dengan data atau grounds dan di bagian akhir muncul satu kalimat sanggahan yang disebut rebuttal. Argumentasi ini merupakan pengembangan dari argumentasi dasar. Data hasil karangan siswa yang berpola C-D-R ditunjukkan pada Tabel 6 . Pada Tabel tersebut argumentasi siswa diawali dengan dua claim, diikuti data, dan rebuttal.

Tabel 6. Pola Argumentasi C-D-R dalam Karangan Siswa

\begin{tabular}{|c|c|c|c|c|c|c|}
\hline \multicolumn{7}{|l|}{ Komponen Argumentasi } \\
\hline Kalimat & $\mathbf{C}$ & D & $\mathbf{W}$ & B & $\mathbf{Q}$ & $\mathbf{R}$ \\
\hline Tomat merupakan salah satu buah yang sangat bermanfaat bagi kesehatan. & $\sqrt{ }$ & & & & & \\
\hline Tomat juga merupakan keluarga dekat dari kentang. & $\sqrt{ }$ & & & & & \\
\hline Tomat memiliki bentuk bulat dan berwarna merah. & & $\sqrt{ }$ & & & & \\
\hline $\begin{array}{l}\text { Tomat yang tersebar di Indonesia adalah tomat buah, tomat sayur dan tomat } \\
\text { lalapan. }\end{array}$ & & $\sqrt{ }$ & & & & \\
\hline Tomat merupakan buah yang sering dijadikan bumbu dan masakan. & & $\sqrt{ }$ & & & & \\
\hline Contohnya sup, sambal tomat, dan berbagai masakan lainnya. & & $\sqrt{ }$ & & & & \\
\hline $\begin{array}{l}\text { Selain itu, tomat juga sering dijadikan jus tomat yang banyak disukai oleh kalangan } \\
\text { orang dewasa. }\end{array}$ & $\sqrt{ }$ & & & & & \\
\hline $\begin{array}{l}\text { Tomat kaya akan vitamin } \mathrm{A} \text {, vitamin } \mathrm{B} \text {, vitamin } \mathrm{B} 2 \text {, vitamin } \mathrm{C} \text {, dan mineral serta } \\
\text { jumlah nutrisi yang baik bagi kesehatan tubuh. }\end{array}$ & & $\sqrt{ }$ & & & & \\
\hline $\begin{array}{l}\text { Manfaat tomat ialah mencegah penguapan darah, menetralisir radikal bebas, } \\
\text { menjaga kesehatan mata, dan melembutkan kulit. }\end{array}$ & & $\sqrt{ }$ & & & & \\
\hline Meskipun banyak manfaat masih banyak orang yang tidak menyukai buah tomat. & & & & & & $\sqrt{ }$ \\
\hline $\begin{array}{l}\text { Manfaat jus tomat yang paling utama adalah memberi asupan vitamin yang sangat } \\
\text { baik untuk menjaga kesehatan mata, dan kulit, serta membantu pencegahan radikal } \\
\text { bebas yang menimbulkan gangguan kesehatan tubuh. }\end{array}$ & & $\sqrt{ }$ & & & & \\
\hline Total & 3 & 7 & & & & 1 \\
\hline Pola Argumentasi & & & & & & \\
\hline
\end{tabular}


Tabel 7. Pola Argumentasi C-D-W-B dalam Karangan Siswa

\begin{tabular}{|c|c|c|c|c|c|c|}
\hline \multicolumn{7}{|l|}{ Komponen Argumentasi } \\
\hline Kalimat & $\mathbf{C}$ & $\mathbf{D}$ & $\mathbf{W}$ & B & $\mathbf{Q}$ & $\mathbf{R}$ \\
\hline Tatanan pendidikan di Indonesia kini mengalamai suatu perubahan. & $\sqrt{ }$ & & & & & \\
\hline $\begin{array}{l}\text { Perubahan ini menyangkut dengan kurikulum yang digunakan dalam dunia } \\
\text { pendidikan. }\end{array}$ & $\sqrt{ }$ & & & & & \\
\hline $\begin{array}{l}\text { Di mana, pada KTSP } 2006 \text { yang sudah lama digunakan diubah dengan kurikulum } \\
2013 .\end{array}$ & & $\sqrt{ }$ & & & & \\
\hline Meskipun masih belum semua sekolah menjalankannya. & & $\sqrt{ }$ & & & & \\
\hline $\begin{array}{l}\text { Kurikulum } 2013 \text { menurut kementerian pendidikan dan kebudayaan hanya } \\
\text { digunakan pada sekolah-sekolah favorit bertaraf internasional yang sudah } \\
\text { terakreditasi A. }\end{array}$ & & & $\sqrt{ }$ & & & \\
\hline $\begin{array}{l}\text { Kurikulum } 2013 \text { ini adalah suatu bentuk susunan pengajaran yang berfokus pada } \\
\text { keterampilan anak dan pembentukan karakter pada anak. }\end{array}$ & & & $\sqrt{ }$ & & & \\
\hline $\begin{array}{l}\text { Bukan hanya itu saja, kurikulum ini sangat berfokus pada proses belajar dengan } \\
\text { mensyukuri pemberian Tuhan terhadap manusia. }\end{array}$ & & & $\sqrt{ }$ & & & \\
\hline $\begin{array}{l}\text { Menurut Wakil Menteri Pendidikan dan Kebudayaan, yaitu Musliar Kasim, } \\
\text { kurikulum } 2013 \text { ini hanya berupa praktik nyata. }\end{array}$ & & & & $\sqrt{ }$ & & \\
\hline Hal ini berujuan untuk meningkatkan kreativitas anak itu sendiri. & & & & $\sqrt{ }$ & & \\
\hline $\begin{array}{l}\text { Dari kurikulum } 2013 \text { ini diharapkan dapat mencetak generasi yang lebih produktif, } \\
\text { kreatif, mampu berinovatif dan efektif. }\end{array}$ & & & & $\sqrt{ }$ & & \\
\hline Dalam kurikulum ini anak didik bisa membentuk sebuah karakter dan sikap. & & & & $\sqrt{ }$ & & \\
\hline $\begin{array}{l}\text { Menurut Meutia Hatta, seorang anggota Dewan Pertimbangan Presiden, } \\
\text { berargumen bahwa kurikulum } 2013 \text { ini memiliki tujuan yang berkualitas yakni } \\
\text { membentuk karakter anak yang cinta tanah air. }\end{array}$ & & $\sqrt{ }$ & & & & \\
\hline $\begin{array}{l}\text { Namun, di pihak masyarakat terjadi cukup banyak penolakan penggunaan } \\
\text { kurikulum } 2013 \text {. }\end{array}$ & & $\sqrt{ }$ & & & & \\
\hline $\begin{array}{l}\text { Menurutnya perubahan ini cenderung karena pemaksaan, meskipun begitu, secara } \\
\text { sederhana tingkat dan pemahaman dan pengetahuan yang dimiliki anak didik akan } \\
\text { mengalami penurunan karena kurang bisa menyesuaikan perubahan yang terkesan } \\
\text { campur aduk. }\end{array}$ & & $\sqrt{ }$ & & & & \\
\hline $\begin{array}{ll} & \text { Total } \\
\end{array}$ & 2 & 5 & 3 & 4 & & \\
\hline Pola Argumentasi & & & C-D- & $\mathbf{W}-\mathbf{E}$ & & \\
\hline
\end{tabular}

\section{Argumentasi Berpola C-D-W-B}

Dari keseluruhan data, ditemukan satu data yang berpola C-D-W-B. Kemunculan backing berfungsi untuk mendukung warrant. Data karangan siswa yang berpola C-D-W-B ditunjukkan pada Tabel 7.

\section{Argumentasi Berpola C-D-W-Q}

Pola ini tidak jauh berbeda dengan pola CD-W-B, hanya backing yang tidak dimunculkan dalam pola ini, tetapi digantikan dengan kemunculan elemen modal qualifier yang menunjukkan derajat kepastian claim atau pernyataan posisi. Dari keseluruhan data diperoleh, delapan (8) data yang memunculkan pola ini. Dari kedelapan data tersebut ada yang memunculkan modal qualifier dua kali mengikuti claim dan ada juga yang hanya satu. Pada Tabel 8 penggunaan modal qualifier ditunjukkan dengan kata "harus".
Data karangan siswa yang berpola C-D-W-Q selengkapnya ditunjukkan pada Tabel 8 .

\section{Argumentasi Berpola C-D-W-R}

Dari keseluruhan data, ditemukan satu data yang berpola C-D-W-R. Data karangan siswa yang berpola C-D-W-R ditunjukkan pada Tabel 9. Pada Tabel 9, argumentasi siswa dibuka dengan claim yang diikuti unsur data dan warrant serta ditutup dengan rebuttal.

\section{Argumentasi Berpola C-D-Q-R}

Salah satu pola argumentasi yang ditemukan dalam karangan siswa adalah pola C-D-Q-R. Data pada Tabel 10 menunjukkan penggunaan modalitas qualifier dengan kata "pasti" dan "pastilah" pada argumentasi siswa. Data karangan siswa yang berpola C-D-Q-R selengkapnya ditunjukkan pada Tabel 10. 
Tabel 8. Pola Argumentasi C-D-W-Q dalam Karangan Siswa

\section{Komponen Argumentasi}

\begin{tabular}{|c|c|c|c|c|c|c|}
\hline Kalimat & $\mathbf{C}$ & D & W & B & $\mathbf{Q}$ & $\mathbf{R}$ \\
\hline $\begin{array}{l}\text { Untuk menciptakan kenyamanan pada lingkungan rumah sekitar serta memberi } \\
\text { contoh untuk lingkungan sekolah maka anda harus memelihara kebersihan } \\
\text { lingkungan rumah terlebih dahulu. }\end{array}$ & $\sqrt{ }$ & & & & $\sqrt{ }$ & \\
\hline Setiap desa telah menerapkan sistem kebersihan lingkungan rumah. & & $\sqrt{ }$ & & & & \\
\hline $\begin{array}{l}\text { Untuk menarik minat warga maka pihak kelurahan desa sering mengadakan } \\
\text { perlombaan kebersihan lingkungan antardesa. }\end{array}$ & & $\sqrt{ }$ & & & & \\
\hline $\begin{array}{l}\text { Terdapat beberapa cara memelihara kebersihan lingkungan rumah yaitu, dengan } \\
\text { membuat tempat sampah di sekitar rumah, membersihkan area sekitar rumah, } \\
\text { membuang sampah pada tempatnya dan masih banyak lagi. }\end{array}$ & & $\sqrt{ }$ & & & & \\
\hline Setiap hari diadakan pemeliharaan lingkungan rumah oleh setiap warga. & & $\sqrt{ }$ & & & & \\
\hline $\begin{array}{l}\text { Namun untuk pemeliharaan sekitar lingkungan selalu diadakan kegiatan bersih- } \\
\text { bersih bersama setiap seminggu sekali. }\end{array}$ & & $\sqrt{ }$ & & & & \\
\hline $\begin{array}{l}\text { Pemeliharaan tersebut meliputi menyapu halaman rumah, membersihkan selokan } \\
\text { sekitar rumah dan lain-lain. }\end{array}$ & & $\sqrt{ }$ & & & & \\
\hline $\begin{array}{l}\text { Dengan adanya kesadaran masyarakat terhadap kebersihan lingkungan maka dapat } \\
\text { berdampak baik terhadap lingkungan yang bersih, semakin baiknya hubungan antar } \\
\text { warga, serta meningkatnya kerja sama agar tetap terjalin. }\end{array}$ & & $\sqrt{ }$ & & & & \\
\hline $\begin{array}{l}\text { Kebersihan lingkungan rumah dapat menjadi contoh untuk pemeliharaan } \\
\text { kebersihan sekolah maupun kebersihan lingkungan sekitar. }\end{array}$ & & $\sqrt{ }$ & & & & \\
\hline $\begin{array}{l}\text { Kebersihan lingkungan rumah akan menyehatkan serta menjaga kebersihan seluruh } \\
\text { keluarga yang terdapat dalam rumah tersebut. }\end{array}$ & & $\sqrt{ }$ & & & & \\
\hline $\begin{array}{l}\text { Memelihara kebersihan ialah segala usaha manusia untuk menjaga kesehatan tubuh } \\
\text { secara berkelanjutan karena kebersihan berbeda dengan kemewahan. }\end{array}$ & & & $\sqrt{ }$ & & & \\
\hline $\begin{array}{lc} & \text { Total } \\
\end{array}$ & 1 & 9 & 1 & & 1 & \\
\hline Pola Argumentasi & \multicolumn{6}{|c|}{ C-D-W-Q } \\
\hline
\end{tabular}

Tabel 9. Pola Argumentasi C-D-W-R dalam Karangan Siswa

\section{Komponen Argumentasi}

\begin{tabular}{|c|c|c|c|c|c|c|}
\hline Kalimat & $\mathbf{C}$ & D & $\mathbf{W}$ & B & $\mathbf{Q}$ & $\mathbf{R}$ \\
\hline Saat ini, Indonesia masih merupakan negara yang berkembang. & $\sqrt{ }$ & & & & & \\
\hline $\begin{array}{l}\text { Jika dibandingkan dengan negara lainnya di Benua Asia, Indonesia masih buruk, } \\
\text { baik dari segi perekonomian maupun pendidikan. }\end{array}$ & $\sqrt{ }$ & & & & & \\
\hline Tentu saja, hal ini disebabkan oleh karakter siswa yang kreatif. & & $\sqrt{ }$ & & & & \\
\hline $\begin{array}{l}\text { Kurangnya jiwa kreatif siswa dapat menurunkan potensi meningkatnya pendidikan } \\
\text { di Indonesia. }\end{array}$ & & $\sqrt{ }$ & & & & \\
\hline $\begin{array}{l}\text { Berdasarkan hal tersebut, timbul beberapa argumen mengenai penerapan game } \\
\text { online guna meningkatnya/mengembangkan kreatifitas siswa. }\end{array}$ & $\sqrt{ }$ & & & & & \\
\hline $\begin{array}{l}\text { Game online adalah game yang terhubung dengan koneksi internet atau LAN } \\
\text { sehingga pemainnya dapat terhubung dengan pemain lainnya yang memainkan } \\
\text { permainan yang sama. }\end{array}$ & & $\sqrt{ }$ & & & & \\
\hline $\begin{array}{l}\text { Menurut Basuki (2010), kretivitas merupakan ungkapan unik dari seluruh pribadi } \\
\text { sebagai hasil interaksi individu, perasaan, sikap dan perilakunya yang dimulai } \\
\text { dengan kemampuan individu untuk menciptakan sesuatu yang baru. }\end{array}$ & & & $\sqrt{ }$ & & & \\
\hline $\begin{array}{l}\text { Jadi, penerapan game online ini selain dapat meluaskan koneksi ke seluruh penjuru } \\
\text { dunia juga dapat membantu siswa untuk mengembangkan jiwa kreativitas mereka } \\
\text { untuk menciptakan sesuatu yang unik tentu saja didukung oleh kecanggihan } \\
\text { teknologi dan ilmu yang baik. }\end{array}$ & & & $\sqrt{ }$ & & & \\
\hline Namun, beberapa argumen lain menentang hal tersebut. & & $\sqrt{ }$ & & & & \\
\hline $\begin{array}{l}\text { Banyak masyarakat utamanya orangtua sang anak merasa bahwa dengan adanya } \\
\text { game online hanya menurunkan minat belajar siswa. }\end{array}$ & & $\sqrt{ }$ & & & & \\
\hline Banyak pelajar yang bercita-cita sebagai gamer yang sukses, bahkan mereka lebih & & $\sqrt{ }$ & & & & \\
\hline
\end{tabular}


rela untuk menghabiskan waktu berjam-jam untuk bermain game online.

Berdasarkan paparan media, menghabiskan waktu berjam-jam di depan komputer dapat memicu penyakit jantung, yaitu penyakit mematikan nomor satu di dunia. Berdasarkan beberapa argumen para ahli maupun mesyarakat mengenai penerapan game online guna mengembangkan kreativitas siswa dapat disimpulkan, bahwa game online dapat membantu siswa dalam mengembangkan kreativitas mereka, karena game online dapat memperluas koneksi siswa dan dapat menjadi media siswa untuk menciptakan sesautu yang baru.

Namun, sebaiknya siswa diberi batasan agar resiko negatif lainnya tidak dapat terwujud.

Potal

\begin{tabular}{|l|l|l|l|l|l|l|}
\hline & & & & & & \\
\hline & & $\sqrt{ }$ & & & & \\
\hline & & & & & & \\
& & $\sqrt{ }$ & & & & \\
& & & & & & \\
\hline & $\sqrt{ }$ & & & & & $\sqrt{ }$ \\
\hline & $\mathbf{4}$ & $\mathbf{8}$ & $\mathbf{2}$ & & & $\mathbf{1}$ \\
\hline
\end{tabular}

Tabel 10. Pola Argumentasi C-D-Q-R dalam Karangan Siswa

\section{Komponen Argumentasi}

\begin{tabular}{|c|c|c|c|c|c|c|}
\hline Kalimat & $\mathbf{C}$ & D & W & B & Q & $\mathbf{R}$ \\
\hline Masalah kerusakan alam pasti sudah tak asing lagi terdengar di telinga kita. & $\sqrt{ }$ & & & & $\sqrt{ }$ & \\
\hline $\begin{array}{l}\text { Banjir, hutan gundul, dan tanah longsor contohnya masalah kerusakan alam ini } \\
\text { sudah sering terjadi di Indonesia. }\end{array}$ & & $\sqrt{ }$ & & & & \\
\hline $\begin{array}{l}\text { Di berbagai daerah seperti di Ibu Kota Jakarta telah rawan terjadi banjir dan } \\
\text { mengakibatkan rumah warga tergenang air sampai mengakibatkan korban jiwa. }\end{array}$ & & $\sqrt{ }$ & & & & \\
\hline $\begin{array}{l}\text { Hal yang masyarakat ingin ketahui pastilah apa penyebab dari masalah-masalah } \\
\text { kerusakan alam. }\end{array}$ & & $\sqrt{ }$ & & & $\sqrt{ }$ & \\
\hline $\begin{array}{l}\text { Mengapa masalah kerusakan alam terus terjadi ? apa solusi dari semua masalah } \\
\text { tersebut ? itulah pertanyaan dari rata-rata warga yang terus mengeluh atas } \\
\text { kerusakan alam yang menimpa Indonesia. }\end{array}$ & & $\sqrt{ }$ & & & & \\
\hline $\begin{array}{l}\text { Padahal seandainya mereka sadar diri atas tindakan dan perilaku yang mereka } \\
\text { lakukan sampai saat ini, pasti mereka malu atas perbuatan diri mereka. }\end{array}$ & $\sqrt{ }$ & & & & & \\
\hline $\begin{array}{l}\text { Mengapa demikian ? karena tindakan dan perilaku manusialah hal utama penyebab } \\
\text { terjadinya kerusakan alam. }\end{array}$ & $\sqrt{ }$ & & & & & \\
\hline Dan mereka sendirilah yang terkena imbasnya. & $\sqrt{ }$ & & & & & \\
\hline $\begin{array}{l}\text { Tindakan dan perilaku mereka yang semena-mena dengan alam tanpa sadar } \\
\text { mereka telah menanam bibit yang akhirnya mereka tuai sendiri, sama halnya } \\
\text { mereka membuang sampah di sembarang tempat, selokan misalnya jika selokan } \\
\text { yang ia telah membuang sampah di sana akan tersumbat dan jika hujan terjadilah } \\
\text { banjir dan akhirnya pemukiman-pemukiman mereka akan tergenang banjir. }\end{array}$ & & $\sqrt{ }$ & & & & \\
\hline $\begin{array}{l}\text { Tindakan atau perilaku kedua yang tanpa sadar manusia lakukan ialah menebang } \\
\text { pohon di hutan secara besar-besaran, apakah mereka mengetahu apa dampak dri } \\
\text { perbuatan mereka ? yaa, sebagian dari mereka tau bahkan mengetahui semua } \\
\text { dampak tersebut tetapi, ia tetap melakukannya tanpa berpikir, dan beberapa juga } \\
\text { dari mereka tidak mengetahui sama sekali dampak dari perbuatan mereka. }\end{array}$ & & $\sqrt{ }$ & & & & \\
\hline $\begin{array}{l}\text { Hutan menjadi gundul adalah akibat dari perbuatan mereka menebang pohon } \\
\text { secara besar-besaran, hal inilah yang juga bisa mengakibatkan banjir secara terus- } \\
\text { menerus. }\end{array}$ & & $\sqrt{ }$ & & & & \\
\hline Apalagi ketika mereka tidak melakukan reboisasi (penanaman hutan kembali). & & $\sqrt{ }$ & & & & \\
\hline Jadi, benar penyebab utama kerusakan alam adalah perilaku manusia sendiri. & $\sqrt{ }$ & & & & & \\
\hline $\begin{array}{l}\text { Tanpa sadar perilaku mereka menjerumuskan mereka pada hal-hal yang tidak } \\
\text { mereka inginkan. }\end{array}$ & $\sqrt{ }$ & & & & & \\
\hline $\begin{array}{l}\text { Sadar dirilah dan saling mengingatkan menjadi salah satu solusi dari permasalahan } \\
\text { tersebut. }\end{array}$ & & & & & & \\
\hline $\begin{array}{l}\text { Jika manusia sadar atas tindakan yang ia lakukan pasti alam tidak akan marah lagi, } \\
\text { dan lingkungan serta alam menjadi alam. }\end{array}$ & & & & & & $\sqrt{ }$ \\
\hline $\begin{array}{lc} & \text { Total } \\
\end{array}$ & 6 & 8 & & & 2 & 1 \\
\hline Pola Argumentasi & \multicolumn{6}{|c|}{ C-D-Q-R } \\
\hline
\end{tabular}


Tabel 11. Pola Argumentasi C-D-W-B-Q dalam Karangan Siswa

\section{Komponen Argumentasi}

\begin{tabular}{|c|c|c|c|c|c|c|}
\hline Kalimat & C & D & W & B & $\mathbf{Q}$ & $\mathbf{R}$ \\
\hline $\begin{array}{l}\text { Manusia tergolong ke dalam makhluk yang produktif dan konsumtif, artinya } \\
\text { manusia dapat memproduksi serta mengkonsumsi berbagai jenis hal. }\end{array}$ & $\sqrt{ }$ & & & & & \\
\hline Baik dalam hal makanan, kebutuhan sehari-hari, sampai hanya untuk sekedar hobi. & $\sqrt{ }$ & & & & & \\
\hline $\begin{array}{l}\text { Semua kegiatan produksi dan konsumsi pastinya meninggalkan bekas, yaitu } \\
\text { sampah. }\end{array}$ & $\sqrt{ }$ & & & & & \\
\hline Sampah ini berdampak besar dalam kehidupan manusia. & $\sqrt{ }$ & & & & & \\
\hline $\begin{array}{l}\text { Pemerintah sendiri sudah membuat aturan tentang masalah pembuangan sampah } \\
\text { disembarang tempat apalagi pada aliran sungai karena dapat menyumbat jalannya } \\
\text { air sungai serta telah menetapkan sanksi bagi para pelakunya. }\end{array}$ & & $\sqrt{ }$ & & & & \\
\hline $\begin{array}{l}\text { Namun di lain pihak, masyarakat tetap saja acuh terhadap peraturan tersebut dan } \\
\text { masih mengotori lingkungan sekitar. }\end{array}$ & & $\sqrt{ }$ & & & & \\
\hline $\begin{array}{l}\text { Kebiasaan membuang sampah sembarang ini bisa ditemukan di mana saja, } \\
\text { misalnya di angkutan umum, di selokan, di sungai, dan bahkan di jalan raya. }\end{array}$ & & $\sqrt{ }$ & & & & \\
\hline $\begin{array}{l}\text { Membuang sampah sembarangan tentu saja membawa dampak yang besar pada } \\
\text { lingkungan maupun pada masyarakat sendiri menurut Rahmat Fajar Lubis, peneliti } \\
\text { pusat. }\end{array}$ & & & $\sqrt{ }$ & & & \\
\hline $\begin{array}{l}\text { Penelitian geoteknologi lipi menyatakan bahwa sampah yang dibuang } \\
\text { sembarangan ke sungai akan membuat sungai tersumbat dan meyebabkan banjir } \\
\text { ketika musim hujan tiba apalagi jika curah hujannya tinggi. }\end{array}$ & & & & $\sqrt{ }$ & & \\
\hline $\begin{array}{l}\text { Selain itu, sampah yang berserakan di mana-mana akan menjadi sarang penyakit } \\
\text { yang bisa mengganggu kesehatan para masyarakat itu sendiri. }\end{array}$ & & & & $\sqrt{ }$ & & \\
\hline $\begin{array}{l}\text { Kita sebagai manusia yang memiliki derajat paling tinggi di antara makhluk hidup } \\
\text { yang lain seharusnya memiliki kesadaran dan tanggung jawab dari diri sendiri } \\
\text { terhadap lingkungan kita. }\end{array}$ & $\sqrt{ }$ & & & & $\sqrt{ }$ & \\
\hline $\begin{array}{l}\text { Kita tidak boleh membuang sampah sembarang karena hal itu akan membawa } \\
\text { dampak negatif bagi diri sendiri dan orang lain. }\end{array}$ & $\sqrt{ }$ & & & & & \\
\hline $\begin{array}{l}\text { Dengan lingkungan yang bersih, maka hidup kita juga tentu akan terasa lebih } \\
\text { nyaman. }\end{array}$ & $\sqrt{ }$ & & & & & \\
\hline $\begin{array}{l}\text { Bumi ini adalah tempat tinggal kita, kita harus menjaganya sebaik mungkin agar } \\
\text { anak dan cucu kita juga bisa menikmati keindahan bumi. }\end{array}$ & $\sqrt{ }$ & & & & & \\
\hline Total & 8 & 3 & 1 & 2 & 1 & \\
\hline Pola Argumentasi & \multicolumn{6}{|c|}{ C-D-W-B-O } \\
\hline
\end{tabular}

\section{Argumentasi Berpola C-D-W-B-Q}

Berdasarkan hasil analisis, ditemukan tiga data yang berpola C-D-W-B-Q ini. Dari keseluruhan pola yang ada, pola inilah yang memunculkan jumlah elemen terbanyak, yaitu elemen claim, data/grounds, warrant, backing, dan modal qualifier. Kelima elemen tersebut memenuhi kriteria setiap elemen yang ditetapkan dalam glosarium analisis data. Dalam ketiga data yang dihasilakan, hanya elemen rebuttal yang tidak muncul dalam pola ini. Data karangan siswa yang berpola C-D-W-B-Q selengkapnya ditunjukkan pada Tabel 11.

\section{Pembahasan}

Hasil penelitian menunjukkan bahwa karangan siswa SMA merepresentasikan beragam pola argumen melalui teks eksposisi. Ditemukan sembilan pola argumen, yakni pola C-D, C-D-W, C-D-Q, C-D-R, C-D-W-B, C-D-W-Q, C-D-W-R, C-D-Q-R, dan C-D-W-B-Q. Dari kesembilan pola tersebut, pola argumen siswa didominasi oleh pola C-D dan C-D. Hasil penelitian tersebut dapat dimaknai bahwa siswa sekolah menengah atas telah memiliki kompetensi dalam dasar-dasar argumen. Elemen claim, data, dan rebuttal adalah elemen dasar dari argumentasi. Elemen argumentasi dalam penalaran minimal terdiri atas pendirian, bukti, dan penyimpulan (Dawud, 2008). Berdasarkan hasil penelitian, disimpulkan bahwa pola argumentasi siswa SMA umumnya berpola dasar.

Hasil penelitian yang menunjukkan dominannya pola dasar dalam argumentasi siswa SMA dalam menulis teks eksposisi dapat dimak- 
nai sebagai keterbatasan berekspresi dalam wacana argumentatif. Siswa SMA cenderung mengembangkan argumentasi berpola dasar secara monoton. Dominannya pola yang bersifat dasar bersumber dari dua hal, yakni (1) kompetensi berargumentasi siswa yang lemah dan (2) sifat teks argumentatif yang rumit. Hasil penelitian ini sejalan dengan temuan Asniar (2016) yang menemukan bahwa kemampuan berargumentasi mahasiswa lemah. Penelitian Amielia, Suciati, dan Maridi (2017) dan Handayani, Murniati, dan Sardianto menunjukkan bahwa elemen-elemen argumentasi yang dominan muncul dalam karangan siswa adalah claim dan warrant. Hal ini dapat dipahami karena elemen tersebut merupakan elemen dasar berargumentasi.

Sisi lain yang perlu dieksplanasi dari hasil penelitian ini adalah munculnya argumentasi siswa SMA dengan yang rumit dan lengkap. Hal ini dapat dilihat pada argumentasi berpola C-D-WB-Q. Elemen-elemen argumentasi yang diperlukan telah digunakan oleh siswa. Temuan tersebut mengindikasikan bahwa kompetensi argumentasi siswa dapat berkembang.

Hasil penelitian yang menunjukkan dominannya pola argumentasi dasar dalam karangan siswa mengisyaraktkan perlunya pengembangan kompetensi berargumentasi siswa. Keterampilan menulis argumen merupakan kompetensi yang menantang dalam pengembangannya. Argumentasi siswa menunjukkan kemampuan bernalarnya sekaligus yang memerlukan pengetahuan dan wawasan luas. Oleh karena itu, pengembangan argumentasi siswa harus dimulai dari pengembangan wawasan dan pengetahuan luas di berbagai bidang. Dalam konteks ini, pembelajaran berbasis teks yang menempatkan bahasa Indonesia sebagai penghela pengetahuan memiliki peran penting. Salam (2009) merekomendasikan proses pembelajaran yang dilakukan mengeksplorasi dan mengobservasi fenomena-fenomena dan fakta fakta sebagai model pembelajaran untuk pengembangan kemampuan berargumentasi. Hasil penelitian Ritasari, Dwiastuti, dan Probosari (2016) menemukan bahwa model pembelajaran berbasis masalah dapat meningkatkan kemampuan berargumentasi siswa.

Pembelajaran teks eksposisi yang diajarkan di sekolah merupakan pembelajaran teks yang melatih siswa untuk berargumen. Teks eksposisi merupakan teks yang menjadi dasar untuk siswa melatih diri mengembangkan argumen dengan mengedepankan sudut pandang yang didukung bukti-bukti untuk memperkuat argumen. Sebagaimana dikemukakan oleh Knapp and
Watkins (2009:191) yang menjelaskan bahwa dalam pembelajaran di sekolah, sebaiknya siswa dikenalkan terlebih dahulu dengan teks eksposisi, yaitu jenis teks dengan jelas berfokus pada satu argumen dan mengedepankan sudut pandang serta memberikan bukti untuk mendukung argumen yang telah diajukan di dalam teks. Maryanto, dkk. (2013:195) pun memiliki pandangan yang sama dengan mengatakan bahwa eksposisi adalah jenis teks yang berfungsi untuk mengungkapkan gagasan atau mengusulkan sesuatu berdasarkan argumentasi dan teks eksposisi hanya berisi satu sisi argumentasi, sisi yang mendukung atau sisi yang menolak. Tujuan sosial eksposisi (berpendapat) memiliki struktur retorika tesisargumen (Harsiati, Titik dkk., 2017:4).

Pendapat para ahli yang telah dikemukakan sejalan dengan hasil penelitian yang menunjukkan bahwa pola argumentasi yang dihasilkan oleh siswa mendominasi pada pola C-D (44 data) dan C-D-Q (46 data). Kedua pola ini merupakan pola dasar yang menunjukkan argumen yang dikemukakan oleh penulis dan diikuti oleh bukti yang mendukung pernyataan tersebut. Adapun kemunculan modalitas atau modal qualifier merupakan kata atau frasa yang menunjukkan derajat kepastian argumen yang dikemukakan dalam claim. Jika dibandingkan dengan penelitian sebelumnya yang dilakukan oleh Syaifuddin, dkk (2011:65) yang juga dilakukan di SMA, pola yang ditemukan pada penelitian ini lebih beragam. Penelitian Syaifuddin, dkk. (2011:65) menghasilkan empat pola argumentasi, yaitu (1) pola C-D-B, (2) pola C-D-W-B, (3) pola C-D-BQ, dan (4) pola C-D-W-B-Q. Yang menjadi perbedaan, penelitian yang dilakukan oleh Syaifuddin, dkk. (2011:65) tidak ditemukan kemunculan elemen rebuttal di dalamnya. Padahal, menurut Kuhn dan Pease (dalam Kathpalia, 2016:28), elemen rebuttal merupakan inti dalam sebuah argumen sehingga dianggap berada pada tingkat yang lebih tinggi dibandingkan argumen yang hanya memuat claim dan grounds. Berdasarkan temuan tersebut, terlihat bahwa elemen rebuttal memiliki peran penting dalam menentukan kualitas ketajaman argumentasi tulisan. Hal ini didasarkan pada penyataan Kuhn dan Pease (dalam Kathpalia, 2016: 28) yang mengatakan bahwa elemen rebuttal merupakan inti dalam sebuah argumen sehingga dianggap berada pada tingkat yang lebih tinggi dibandingkan argumen yang hanya memuat claim dan grounds. Grounds dalam hal ini mencakup elemen data, warrants, dan backing. Menurutnya, argumen yang baik memiliki lebih banyak elemen yang 
menandakan bahwa argumen tersebut dikembangkan sepenuhnya, dan meskipun demikian, argumen tersebut tidak akan bias di satu sisi karena munculnya elemen sanggahan (rebuttal).

Teks ekpsosisi dalam pembelajaran berbasis genre teks bukan lagi hanya sekadar teks yang menjelaskan informasi, namun juga menguraikan argumentasi yang menjadi bagian struktur di dalamnya. Hal ini didasarkan pada teori genre yang lebih menekankan pada tujuan. Eggins (2004:5) menjelaskan bahwa teks merupakan satu kesatuan bahasa yang lengkap secara sosial dan kontekstual, yang mungkin bisa dalam bentuk bahasa lisan maupun tulis dan lebih disukai dari awal sampai akhir. Sebagaimana pula dikemukakan oleh Maryanto dkk. (2013) bahwa genre atau jenis tulisan merupakan proses sosial yang bertahap dan berorientasi pada tujuan. Fungsi sosial dari genre ini adalah untuk menyalurkan informasi mengenai fakta-fakta penting di dunia (Martin, 2009; Emilia, 2013:8; Zainurrahman, 2011:67)

Temuan ini sejalan dengan penelitian sebelumnya yang menunjukkan bahwa berbagai studi empiris pada tulisan argumentatif terdahulu (Ferretti, MscArthur, \& Dowdy, 2000; Nussbaum \& Kardash, 2005; Persky, Daane, \& Jin, 2003) menunjukkan bahwa siswa seringkali membuat tulisan yang berisi pernyataan dengan alasan pendukung (grounds), tetapi gagal dalam memasukkan bukti yang relevan atau memasukkan perspektf alternatif (rebuttal), selain itu juga siswa tidak kritis mengevaluasi argumen lain.

\section{DAFTAR PUSTAKA}

Amelia, S. D., Suciati, dan Maridi. 2017. Profil Keterampilan Argumentasi Siswa SMA Negeri 5 Surakarta. Prosiding Seminar. Dipresentasikan pada Seminar Nasional Pendidikan Sains II UKSW, Yogyakarta.

Asniar. 2016. Profil Penalaran Ilmiah dan Kemampuan Berargumentasi Mahasiswa Sains dan Non-sains. Jurnal Penelitian dan Pembelajaran IPA, 2 (1):30-41.

Dawud. 2008. Penalaran dalam Karya Tulis Populer Argumentatif. Bahasa dan Seni, 31 (1):41-48.

Dilianzia, dkk. 2015. Penerapan Teori Argumen dalam Penulisan Seni Rupa: Kasus Buku Lima Maestro Seni Rupa Modern Indonesia. Jurnal Tingkat Sarjana Bidang Seni Rupa, 1:1-17.

Eggins, Suzanne. 2004. An Introduction to Systemic Functional Linguistics. London: Continuum.

Emilia, E. 2011. Pendekaatan Genre-Based dalam Pengajaran Bahasa Inggris: Petunjuk untuk Guru. Bandung: Rizki Press.

\section{PENUTUP}

Berdasarkan hasil penelitian ditemukan sembilan pola argumentasi dalam karangan siswa SMA. Kesembilan pola tersebut adalah pola CD, C-D-W, C-D-Q, C-D-R, C-D-W-B, C-D-WQ, C-D-W-R, C-D-Q-R, dan C-D-W-B-Q. Pola yang paling banyak muncul, yaitu pola C-D-Q dan pola C-D. Pola C-D-Q muncul sebanyak $41,81 \%$ (46 data) dan pola C-D muncul sebanyak $40 \%$ (44 data). Kedua pola ini mendominasi keseluruhan data yang ada dan masih merupakan pola dasar yang menjadi sruktur dalam sebuah argumentasi. Dengan demkian, masih diperlukan usaha untuk meningkatkan keterampilan menulis karangan yang mengandung argumentasi.

Untuk penelitian selanjutnya diperlukan analisis argumentasi karangan tidak hanya dari struktur elemen Toulmin, tetapi juga dari kualitas ketajaman isi karangan. Untuk itu, diperlukan pula pengembangan instrumen yang dapat digunakan untuk mengukur ketajaman isi argumentasi yang sekaligus mengukur struktur argumentasi.

\section{UCAPAN TERIMA KASIH}

Ucapan terima kasih disampaikan kepada mitra bestari (reviewers) yang telah memberikan masukan, kritik, dan saran perbaikan dalam penulisan artikel ini. Saran dan komentar yang diberikan telah membantu penulis meningkatkan kualitas artikel ini.

Ferretti, R. P., MacArthur, C. A., \& Dowdy, N. S. 2000. The Effects of An Elaborated Goal on the Persuasive Writing of Students with Learning Disabilities and Their Normally Achieving Peers. Journal of Educational Psychology, 92:694-702, doi:10.10371/130220663.92.4.694.

Lewis, W. E., \& Andrews-Weckerly, S. 2009. Do Goals Affect the Structure of Stu-dents' Argumentative Writing Strategies? Journal of Educational Psychology, 101:577-589.

Hanyani, P., Murniati, dan Sardianto H. S. 2016. Analisis Argumentasi Peserta Didik Kelas X SMA Muhammadiyah 1 Palembang dengan Menggunakan Model Argumentasi Toulmin. Jurnal Inovasi dan Pembelajaran Fisika, 2 (1): 6068.

Harsiati, Titik dkk. 2017. Buku Guru Bahasa Indonesia SMP/MTs Kelas VII. Kemendikbud: Pusat Kurikulum dan Perbukuan. 
84 RETORIKA: Jurnal Bahasa, Sastra, dan Pengajarannya, Volume 12, Nomor 1, Februari 2019, hlm. 71-84

Kathpalia, S. S., \& See, E. K. 2016. Improving Argumentation through Student Blogs. System, 58: 25-36.

Knapp, P. \& Watkins, M. 2009. Genre, Text, Grammar Technologies for Teaching: An Assesing Writing. Australia: University of New South Wales Press.

Maryanto. 2013. Bahasa Indonesia Ekspresi Diri dan Akademik Kelas X. Jakarta: Kementerian Pendidikan dan Kebudayaan.

Martin, J. R \& D. Rose. 2009. Genre Relation: Mapping Culture. London \& Oakville: Equinox.

Moleong, L. J. 2017. Metodologi Penelitian Kualitatif. Bandung: Ramaja Rosdakarya.

Nussbaum, M. E., \& Kardash, C. M. 2005. The Effects of Goal Instructions and Text on the Generation of Counterarguments During Writing. Journal of Educational Psychology, 97:157-169.

Pritasari, A. C., S. Dwiastuti, dan R. M. 2016. Probosari Peningkatan Kemampuan Argumentasi melalui Penerapan Model Problem Based Learning pada Siswa Kelas X MIA 1 SMA
Batik 2 Surakarta Tahun Pelajaran 2014/2015. Jurnal Pendidikan Biologi, 8 (1): 1-7.

Salam. 2009. Penalaran dalam Karya Tulis Ilmiah. Makassar: Badan Penerbit UNM.

Syaifudin, A. 2011. Penalaran Argumen Siswa dalam Wacana Tulis Argumentatif sebagai Upaya Membudayakan Berpikir Kritis di SMA. Lingua, 7 (1):65-76.

Toulmin, S. E., \& Rieke, R. D. J. 1979. An Introduction to Reasoning. New York: Macmillan Publishing Company.

Toulmin, S. E. 2003. The Uses or Argument. New York: Cambridge University Press.

Viyanti. 2015. The Profile of Argumentation Skill Using Toulmin Argumentation Pattern: Analysis in the Archimedes Principal on the Students of SMA Kota Bandar Lampung. Jurnal Pendidikan IPA Indonesia-Indonesian Journal of Science Education, 4(1):86-89.

Weston, A. 2007. Kaidah Berargumentasi. Yogyakarta: Pustaka Pelajar

Zainurrahman. 2011. Menulis Teori Hingga Praktik. Bandung: Alfabeta. 